\title{
Pengaruh Kecerdasan Emosional dan Spritual Terhadap Sikap Etis Pekerja Pada PT Asuransi Umum Bumiputera Muda 1967
}

\author{
PRAMA WIDAYAT \\ Dosen Fakultas Ekonomi Universitas Lancang Kuning \\ Jalan Yos Sudarso KM 8 Rumbai \\ Telp (0761) 52581 email : pramawidayat@yahoo.com
}

\begin{abstract}
The objective of the research to know and explain the correlation of influencing variables of emotional quotients, spiritual quotients on employees ethical attitudes. The method used in this study is to survey approach of 100 employees at PT Asuransi Umum Bumiputera Muda 1967 at Head Office, Kebayoran and Jakarta khusus. The Technique of sampling used in this research is done by area sampling. The result of the research showed that the variables of emotional quotients, spiritual quotients on employees ethical attitudes. Emotional quotients and spiritual quotients altogether simultaneously influence employees ethical attitudes, while the rest was influence by the other variables which did not to be explain in the research.
\end{abstract}

Keywords: Emotional Quetion, Spritual Quetion and ethical attitudes

Di lingkungan dunia kerja, keseluruhan aspek kecerdasan harus seimbang dengan faktor SQ dan EQ yaitu kemampuan untuk menghayati nilai dan makna-makna, memiliki kesadaran diri, fleksibel dan adaptif masih terbatas kepada kemampuan diri sendiri yang suatu saat dapat hilang tanpa kepercayaan dan keyakinan kekuatan transedental yang memberikan energi bagi manusia. Penerapan keseluruhan aspek kecerdasan ini sangat efektif kalau dilakukan pekerja dalam kehidupan sehari-hari, sehingga pekerja dapat mengelola masalah-masalah mereka. Dalam Kamus Lengkap Bahasa Indonesia (Dani, 2002) didefinisikan sikap sebagai perbuatan dan sebagainya yang berdasarkan pendirian, pendapat atau keyakinan.

Sementara definisi sikap menurut para ahli hingga saat ini masih berbeda pandangan, yang secara umum pandangan tersebut dibagi ke dalam tiga kelompok, antara lain: 1) Kelompok pertama yang diwakili oleh Thurstone, Likert, dan Osgood memandang sikap sebagai berikut : Sikap merupakan bentuk evaluasi atau reaksi perasaan terhadap suatu objek, yang dapat berupa mendukung atau memihak maupun tidak mendukung atau tidak memihak; 2) Kelompok kedua yang diwakili oleh Chave, Bogardus, LaPieree,
Mead, dan Allport memandang sikap sebagai berikut : Sikap merupakan kesiapan untuk bereaksi terhadap suatu objek dengan cara tertentu apabila individu dihadapkan pada suatu stimulus yang menghendaki adanya respon; 3) Kelompok ketiga yang diwakili oleh Secord \& Backman memandang sikap sebagai berikut : Sikap merupakan konstelasi komponen-komponen kognitif, afektif, dan konatif yang saling berinteraksi dalam memahami, merasakan, dan berperilaku terhadap suatu objek (Azwar, 2004).

Pemahaman EQ dan SQ mudah dilakukan melalui kegiatan tatap muka secara langsung dengan menggugah hati nurani setiap pekerja untuk berperilaku baik dan mampu mengendalikan diri serta berinteraksi dengan orang lain secara baik pula. Kalau ini sudah dilakukan secara efektif dengan memasukkan semua aspek kecerdasan yang diperlukan, maka pekerja akan memiliki perilaku yang dapat diterima dalam mereka berhubungan dengan sesama.

Semakin ketatnya persaingan bisnis di bidang jasa terutama di bidang asuransi, karena pada hakekatnya jasa adalah bagaimana memberikan pelayanan yang excellent kepada pelanggan dengan meningkatkan performance manajemen 
secara internal, mulai dari kedisiplinan waktu bekerja, tidak membedakan antara nasabah besar dan nasabah kecil, kecepatan dan ketepatan dalam bekerja, menjaga sikap dan prilaku selama bekerja serta yang terpenting adalah bagaimana menjaga perasaan dan mampu memahami apa yang dibutuhkan customer. Orientasi etis ini diperlukan dalam mengambil sikap yang wajar dalam suasana pluralisme. Pluralisme moral diperlukan karena: 1) Pandangan moral yang berbedabeda karena adanya perbedaan suku, daerah budaya dan agama yang hidup berdampingan; 2) Modernisasi membawa perubahan besar dalam struktur dan nilai kebutuhan masyarakat yang akibatnya menantang pandangan moral tradisional; 3) Berbagai ideologi menawarkan diri sebagai penuntun kehidupan, masing-masing dengan ajarannya sendiri tentang bagaimana manusia harus hidup. (Basuki, 2007).

Etika secara umum dapat dibagi menjadi etika umum yang berisi prinsip serta moral dasar dan etika khusus atau etika terapan yang berlaku khusus. Etika khusus ini masih dibagi lagi menjadi etika individual dan etika sosial. Etika sosial dibagi menjadi: (1) Sikap terhadap sesama, (2) Etika keluarga, (3) Etika profesi misalnya etika untuk pustakawan, arsiparis, dokumentalis, pialang informasi, (4) Etika politik, (5) Etika lingkungan hidup dan (6) Kritik ideologi (Pendit, 2000).

Secara umum bumida telah memberikan training ESQ untuk seluruh karyawan demi mewujudkan tujuan perusahaan yaitu memberikan nilai lebih bagi stakeholder. Sesuai dengan budaya dalam perusahaan PT Asuransi Umum Bumiputera Muda 1967 (Bumida). Disiplin dan taat prosedur, di implementasikan dengan tingkat keterlambatan karyawan harus dibawah 3\% dari total 300 karyawan seluruh Indonesia. Kemudian Menghargai nasabah, namun terkadang hal ini juga diabaikan karena jika nasabah tersebut berasal dari AJB Bumiputera, Anggota DPR dan pihak-pihak yang memiliki hubungan dengan Internal perusahaan maka mereka ini akan mendapatkan perlakuan khusus terutama dalam hal ijin Otorisasi. Hal yang tak kalah pentingnya adalah menjaga kestabilan emosi dalam bekerja karena hal ini akan berimbas pada suasana lingkungan kerja, memang besarnya beban kerja yang dihadapi terkadang membuat suasana hati dan pikiran menjadi labil, pada akhirnya perkataan yang dilontarkan bisa menyinggung rekan kerja bahkan bisa kepada customer.

Itulah beberapa problema yang terjadi di PT. Asuransi Umum Bumiputera Muda 1967. Penekanan penelitian ini pada dimensi EQ dan SQ sebagai bagian dari aspek individual yang mempengaruhi sikap etis pekerja didasarkan pada ungkapan bahwa kecerdasan merupakan kemampuan untuk mengarahkan pikiran atau tindakan bertindak dengan tujuan tertentu (Binet \& Simon dalam Azwar, 2004). Sekaligus penelitian ini apakah relevan dengan penelitian yang dilakukan oleh Ludigdo (2001 dan 2006), serta Purnamasari (2006) bahwa ESQ mempengaruhi sikap etis seseorang.

Maka dari itu peneliti memfokuskan penelitian pada PT. Asuransi Umum Bumiputera Muda 1967, yaitu tempat peneliti bekerja. Perusahaan ini berdiri tahun 1967 dan sekarang memiliki 44 cabang Konvensional dan 3 cabang Syariah di seluruh Indonesia. Tetapi peneliti hanya memfokuskan di Cabang Kebayoran, Kantor Pusat dan Jakarta Khusus dengan jumlah karyawan 100 Orang.

Melihat latar belakang masalah yang telah disebutkan diatas maka dapat dilakukan identifikasi masalah yaitu: 1) Persoalan bagaimana mengendalikan emotional dari dalam diri sehingga dalam bekerja tercipta suasana saling menghargai; 2) Sikap spritual yang masih labil dengan masih memandang nasabah berdasarkan asal usulnya, serta masih kurangnya disiplin terhadap waktu karena ini semua bersumber dari kesadaran dari dalam diri; 3) Pemahaman ESQ yang masih sebatas pada emosi dan agama semata, padahal ESQ lebih daripada itu. 


\section{METODE}

Penelitian ini menggunakan pendekatan deskriptif kuantitatif. Sampel yang diteliti adalah sebanyak 100 orang, dengan rincian 50 orang di Kantor Pusat, 40 orang di Cabang Jakarta Khusus dan 10 orang di Cabang Kebayoran. Pengumpulan data dilakukan dengan daftar pertanyaan tertulis (kuesioner). Pengujian ini dimaksudkan untuk mengetahui apakah EQ dan SQ mempunyai pengaruh yang signifikan baik secara bersama-sama maupun secara parsial terhadap sikap etis, dalam penelitian ini peneliti mengunakan metode Regresi Linier Berganda.

\section{HASIL}

Berdasarkan hasil penelitian sebagaimaa diuraikan pada uraian berikut ini mengenai pengaruh Kecerdasn Emosional (EQ) Terhadap Sikap Etis, sebagai berikut:

Tabel 1.

Hasil Analisis Koefisien Regresi linear Berganda

\begin{tabular}{|c|c|c|c|c|c|c|}
\hline & & \multicolumn{2}{|c|}{$\begin{array}{l}\text { Unstandardized } \\
\text { Coefficients }\end{array}$} & \multirow{2}{*}{\begin{tabular}{|c|}
$\begin{array}{l}\text { Standardized } \\
\text { Coefficients }\end{array}$ \\
Beta \\
\end{tabular}} & \multirow[b]{2}{*}{$\mathrm{t}$} & \multirow[b]{2}{*}{ Sig. } \\
\hline \multicolumn{2}{|c|}{ Model } & $\mathrm{B}$ & Std. Error & & & \\
\hline \multirow[t]{3}{*}{1} & (Constant) & 3.210 & 2.277 & & 1.410 & .162 \\
\hline & Emotional & .143 & .067 & .263 & 2.133 & .035 \\
\hline & Spritual & .267 & .081 & .490 & 3.974 & .000 \\
\hline
\end{tabular}

Dari tabel 1 di atas, maka dapat dibuat persamaan regresi berganda sebagai berikut :

$$
\begin{aligned}
& Y=a+b x_{1}+b x_{2} \\
& Y=3,210+0,143 X_{1}+0,267 X_{2}
\end{aligned}
$$

Dari persamaan diatas, didapat nilai koefisien regresi untuk variabel kecerdasan emosional sebesar 0,143 yang berarti jika kecerdasan emosional meningkat 1, maka akan mengakibatkan meningkatkan sikap etis karyawan sebesar 0,143, maksudnya semakin karyawan mengetahui perasaan sendiri dan memahami orang lain maka sikap etis mereka juga akan meningkat. Dari persamaan regresi tersebut juga didapat nilai koefisien regresi untuk variabel kecerdasan spiritual sebesar 0,267 yang berarti jika kecerdasan spiritual meningkat 1, maka akan mengakibatkan meningkatnya sikap etis karyawan sebesar 0,267, Maksudnya semakin karyawan tersebut dapat menghadapi dan memecahkan persoalan makna dan nilai, maka sikap etis pekerja itu akan meningkat juga, dengan asumsi faktor lain dianggap konstan atau tetap.

Menyatakan bahwa kecerdasan emosional berpengaruh signifikan terhadap sikap etis pekerja di PT Asuransi Umum Bumiputera Muda 1967 maka Ha diterima. Sebagaimana menurut teori Goleman (2005) mendefinisikan EQ adalah kemampuan mengenali perasaan diri sendiri, serta mengelola emosi dengan baik pada diri sendiri dan dalam hubungan dengan orang lain. Tingkat emotional yang stabil akan mendukung seorang karyawan untuk bersikap lebih bijak dan etis dalam menghadapi berbagai karakter manusia terutama dalam dunia bisnis asuransi yang notabenenya memberikan layanan/service kepada pelanggan.

Patton (1998) menyebutkan bahwa orang yang cerdas dapat bekerja lebih baik daripada pekerja lainnya. Memiliki kecerdasan emosional pada taraf tinggi ternyata sangat berguna dalam lingkungan kerja. Orang-orang dengan tingkat kecerdasan emotional yang tinggi akan lebih mudah peka dan respect dengan orang-orang disekitar, ia mengetahui dan memahami kesulitan dan kesusahan yang dihaapi oleh oran lain. Dengan demikian karyawan yang memiliki EQ yang tinggi akan disukai oleh customer karena selalu menjadi pendengar dan mencarikan solusi terhadap permasalahan yang dihadapi. Pada akhirnya image perusahaan akan positif dimata customer karena karyawan yang ada didalamnya mampu menampilkan dan memperlihatkan sikap yang etis ketika menghadapi kesulitan yang beraneka ragam.

Kemudian mengenai pengaruh Kecerdasan Spritual (SQ) Terhadap Sikap Etis, dapat diuraikan sebagai berikut:

Tabel 2.

Hasil Pengujian t-Statistik koefisien $\beta$

\begin{tabular}{|l|c|c|l|}
\hline Keterangan & sig. & $A$ & Kesimpulan \\
\hline $\begin{array}{l}\text { Kecerdasan } \\
\text { Emosional }\end{array}$ & 0,035 & 0,05 & Signifikan \\
\hline $\begin{array}{l}\text { Kecerdasan } \\
\text { Spiritual }\end{array}$ & 0,000 & 0,05 & Signifikan \\
\hline
\end{tabular}

Sumber : Data olahan SPSS 17 
Dari hasil perhitungan pada Tabel 3, diperoleh tingkat signifikan variabel kecerdasan spiritual sebesar 0,000 lebih kecil dari alfa 0,05 dan nilai t-hitung $(3,974)>\mathrm{t}-$ tabel $(1,984)$ Hal ini menunjukkan bahwa variabel kecerdasan spiritual berpengaruh signifikan terhadap sikap etis pekerja. Maksudnya semakin karyawan tersebut dapat menghadapi dan memecahkan persoalan makna dan nilai, mengetahui dan mengembangkan potensi yang mereka miliki, maka sikap etis karyawan itu akan meningkat juga.

Menyatakan bahwa kecerdasan spiritual berpengaruh signifikan terhadap sikap etis karyawan PT Asuransi Umum Bumiputera Muda 1967. Hal ini di dukung oleh Zohar \& Marshall (2002), yang mengatakan SQ dapat menyatukan hal-hal yang bersifat intrapersonal, serta menjembatani antara diri dan orang lain, dan wujud dari SQ ini adalah sikap moral yang dipandang luhur oleh seseorang. dan sesuai dengan pendapat Agustian (2006), yang mengatakan kecerdasan spiritual adalah kemampuan untuk memberikan makna spiritual terhadap pemikiran, perilaku dan kegiatan.

Selanjutnya pengaruh EQ dan SQ Terhadap Sikap Etis, pada hipotesis ketiga diterima bahwa kecerdasan emosional dan kecerdasan spiritual secara bersama-sama berpengaruh signifikan terhadap sikap etis karyawan PT Asuransi Umum Bumiputera Muda 1967 (Bumida). Dengan demikian hasil penelitian ini mendukung apa yang dikemukakan oleh Salovey \& Mayer (1990) dalam Svyantek (2003), Goleman (2005), Zohar \& Marshall (2002), serta Ummah dkk (2003). Hasil penelitian ini secara parsial juga mendukung penelitian Maryani \& Ludigdo (2001), Baihaqi (2002), serta Clark \& Dawson (1996). Namun tidak mendukung apa yang dikemukan oleh Tikollah dkk (2006), Binet \& Simon, Wechsler (Azwar, 2004), dan Freeman (Fudyartanta, 2004).

ESQ bukanlah hanya sebatas kepemimpinan atau pengurusan tetapi suatu inovasi terkini yang menekankan aspek kepentingan kecerdasan spritual bagi setiap manusia. ESQ akan melahirkan manusia yang unggul dari sudut emosi dan spritual dengan cara mengembangkan potensi kepribadian (Mubarok, 2010). Tentu hal ini tidaklah berlebihan karena dunia asuransi maupun dunia usaha keseluruhan harus mengedepakan etika dalam melayai customer. Tidak mudah untuk merapkannya tetapi jika ada keseriusan dalam memperbaiki etika dan tingkah laku dalam bekerja, maka setiap karyawan tidak hanya dituntut cerdas IQ tentu juga harus menyeimbangkan dengan EQ dan SQ. Karena ESQ merupakan faktor utama yang menentukan karakter dan kepribadian seseorang untuk bersikap secara etis terhadap orang lain.

\section{PEMBAHASAN}

\section{Kecerdasan Emosional}

Dari hasil penelitian ini dapat disampaikan bahwa tingkat kecerdasan emosional seseorang berpengaruh terhadap sikap, dimana Model kecerdasan emosional untuk pertama kalinya diusulkan dalam tulisan pada "Emotional Intelligences", Imagination, Cognition, and Personality (Mayer, 1997). Lima wilayah utama kecerdasan emosi adalah mengenali diri sendiri, mengelola emosi, memotivasi diri sendiri, mengenali emosi orang lain, dan membina hubungan.

Akar kata emosi adalah movere kata kerja bahasa latin yang berarti menggerakkan atau bergerak ditambah awalan " $"$ " menjadi emovere yang berarti bergerak jauh. Menyiratkan bahwa kecendrungan bertindak merupakan hal mutlak dalam emosi. (Goleman, 2006)

Kecerdasan Emosional (EQ) adalah kemampuan mengetahui perasaan sendiri dan orang lain, serta menggunakan perasaan tersebut menuntun pikiran dan perilaku seseorang (Salovey dalam Sadana, 2006). EQ adalah kemampuan mengetahui perasaan sendiri dan perasaan orang lain, serta menggunakan perasaan tersebut menuntun pikiran dan perilaku seseorang (Mayer, 1990 dalam Svyantek, 2003).

Selain itu, Goleman (2005) mendefinisikan EQ adalah kemampuan 
mengenali perasaan diri sendiri, serta mengelola emosi dengan baik pada diri sendiri dan dalam hubungan dengan orang lain. Goleman (2005) juga mengadaptasi model Salovey-Mayer, membagi EQ dalam lima sosial yang meliputi: kesadaran diri, pengaturan diri, motivasi, empati, dan kecakapan dalam membina hubungan dengan orang lain. Kelima sosial tersebut dikelompokkan kedalam dua kecakapan, yaitu: a). kecakapan pribadi; yang meliputi kesadaran diri, pengaturan diri, dan motivasi; serta b). Kecakapan sosial; yang meliputi empati dan keterampilan sosial (Goleman, 2005).

Steiner (1997) menyatakan bahwa EQ mencakup lima komponen, yaitu: mengetahui perasaan diri sendiri, memiliki empati, belajar mengatur emosi sendiri, memperbaiki kerusakan sosial , dan interaktifitas emosional. Cooper dan Sawaf (1998) merumuskan EQ sebagai sebuah titik awal model empat batu penjuru yang terdiri dari: kesadaran emosi, kebugaran emosi, dan kedalaman emosi. (Armansyah, 2006).

Untuk mengukur Emotional Question terdapat 5 (lima) pendekatan yang dilakukan menurut Tikollah (2006) : 1) Mengenali diri sendiri, mampu mengenali kekurangan dan kelemahan secara pribadi; 2) Mengelola emosi, mampu mengendalikan emosi dalam kondisi normal maupun dalam kondisi tertekan, atau dengan kata lain mampu mengelola emosi secara cerdas; 3) Memotivasi diri sendiri, tidak takut akan tantangan pekerjaan yang akan dihadapi bahkan mampu memberikan sumbangan ide atau pemikiran; 4) Mengenali emosi orang lain, mampu menempatkan posisi disaat orang lain membutuhan kita untuk emberikan masukan ataupu ide serta mampu mengintrospeksi diri sendiri; 5) Membina hubungan, dalam berkomukasi baik secara verbal maupun non verbal tetap menjaga sopan santun dan etika dengan orang lain.

Bradberry (2007) menjelaskan bahwa Kecerdasan emosional adalah dua produk dari dua skill utama : kompetensi personal dan kompetensi sosial. Kompetensi personal lebih berfokus pada diri sendiri sebagai seorang individu dan terbagi kedalam skill kesadaran diri dan menejemen diri. Kompetensi sosial lebih berfokus pada bagaimana hubungan seseorang dengan orang lain dan terbagi kedalam skill kesadaran sosial dan skill manajemen hubungan sosial. Karyawan dengan tingkat kecerdasan spritual yang tinggi merupakan orang-orang yang yang melewati satu fase kehidupan sebagai manusia dewasa, dimana individu tersebut bukan hanya mementingkan diri sendiri karena kemampuan spritual disini bukan hanya diartikan secara sempit yaitu hanya hubungan manusia dengan tuhan tetapi lebih dari itu. Karena selain berhubungan dengan tuhan manusia juga sebagai makhluk sosial yang butuh berinteraksi dengan orang lain. Disinilah peran SQ yang sesungguhnya akan berfungsi dalam menghadapi persoalan yang begitu komplek dan beberapa karakter manusia yang ditemui. Jika SQ telah terlatih maka walaupun dihadapkan dengan persoalan yang besar semua akan dihadapi dengan bijak dan tenang tanpa ada yang tersakiti karena dalam mengatasi masalah orang-orang dengan SQ yang terlatih pasti akan memperhatikan sikap yang etis.

Disamping itu kecerdasan emosional (EQ) juga dapat menentukan seberapa baik seseorang menggunakan keterampilanketerampilan yang dimilikinya, termasuk keterampilan intelektual. Dari berbagai pendapat ahli diatas dapat disimpulakan bahwa EQ adalah kemampuan seorang individu untuk memahami diri sendiri dan orang lain, dan kemampuan untuk membina hubungan dengan khalayak banyak.

Dalam sikap terdapat 3 (tiga) komponen utama yaitu : Pertama komponen kognitif (cognitive component) berkeyakinan bahwa "diskriminasi itu salah" merupakan sebuah pernyataan evaluatif, opini semacam ini adalah bagian dari sikap yang menentukan tingkatan untuk bagian yang lebih penting dari sebuah sikap. Kedua komponen afektif (affective component) merupakan segmen emosional atau perasaan dari sebuah sikap, perasaan bisa menimbulkan hasil akhir perilaku. Ketiga komponen perilaku (behavior component) 
dari sebuah sikap merujuk pada suatu maksud untuk berperilaku dalam cara tertentu terhadap seseorang atau sesuatu. Ketiga komponen dari sikap tersebut diatas terdiri atas tiga komponen yaitu kesadaran, perasaan dan perilaku sangat bermanfaat dalam memahami kerumitan hal ini dan hubungan potensial antara sikap dan perilaku. Perlu penekanan bahwa komponen-komponen ini saling berkaitan dan tidak dapat dipisahkan.

Terkadang setiap manusia dihadapkan pada situasi dimana antara sikap dan perilaku tidaklah seimbang atau terjadi inkonsistensi. Untuk melihat konsistensi sebuah sikap, Robbin dan Judge (2008) menyatakan tahun 1950-an Leon Festinger mengemukakan teori "ketidakseimbangan kognitif (cognitive dissonance)" bahwa teori ini berusaha menjelaskan hubungan antara sikap dan perilaku, merujuk pada ketidaksesuaian yang dirasakan oleh seorang individu antara dua sikap atau lebih, atau antara perilaku dan sikap. Tentunya tidak ada seorangpun yang individu yang bisa sepenuhnya menghindari ketidaksesuaian, apapun bentuk ketidakkonsistenan tidaklah menyenangkan dan bahwa individu akan berusaha mengurangi ketidaksesuaian dan ketidaknyamanan tersebut.

\section{Kecerdasan Spritual (SQ)}

Dari sisi spritual juga mempengaruhi bagaimana seseorang bersikap, kematangan spritual membuat individu lebih menjaga, bertutur kaca, berkomunikasi dan berinteraksi dengan lingkungan kerja. Penggagas istilah teknis SQ (kecerdasan spiritual) dikatakan bahwa kalau IQ bekerja untuk melihat ke luar (mata pikiran), dan EQ bekerja mengolah yang di dalam (telinga perasaan), maka SQ (spiritual quotient) menunjuk pada kondisi 'pusat-diri' dalam kehidupannya. (Zohar, 2002).

Begitu luasnya aspek spritual, jika dibahas semua maka akan memakan waktu yang lama dan akan terjadi bias dalam pembahasan, maka dapat dipilah dalam beberapa aspek menurut Zohar (2002) sebagai berikut: 1) Kemampuan untuk bersikap fleksibel, memiliki kesadaran secara moral dan tidak terlalu kaku dalam bertindak; 2) Adanya tingkat kesadaran diri yang tinggi, setiap tindakan dan ucapan selalu penuh pertimbangan karena semuanya itu akan dipertanggungjawabkan dihadapan tuhan sesuai dengan agama dan kepercayaan masing-masing; 3) Kemampuan untuk menghadapi dan memanfaatkan penderitaan, selalu bangkit dan terus berusahan karena percaya bahwa tuhan itu tidak tidur, dan juga percaya setiap usaha yang sungguh-sungguh pasti akan berhasil; 4) Kemampuan untuk menghadapi dan melampaui perasaan sakit, yaitu penuh rasa optimis dan pantang untuk mengeluh; 5) Kualitas hidup yang diilhami oleh visi dan nilai-nilai, yaitu memahami dan memiliki tujuan yang ingin dicapai kemudian hari dan tidak memandang segala sesuatu dari materi, serta mampu untuk saling berbagi.

Kecerdasan spiritual adalah kecerdasan yang mengangkat fungsi jiwa sebagai perangkat internal diri yang memiliki kemampuan dan kepekaan dalam melihat makna yang ada di balik kenyataan apa adanya ini. Kecerdasan ini bukan kecerdasan agama dalam versi yang dibatasi oleh kepentingan-pengertian manusia dan sudah menjadi ter-kavling-kavling sedemikian rupa. Kecerdasan spiritual lebih berurusan dengan pencerahan jiwa. (Armansyah, 2006). SQ adalah kecerdasan untuk menghadapi dan memecahkan persoalan makna dan nilai yang menempatkan perilaku dan hidup manusia dalam konteks yang lebih luas dan kaya yang memungkinkan seseorang untuk menyatukan hal-hal yang bersifat intrapersonal dan interpersonal, serta menjembatani kesenjangan antara diri sendiri dan orang lain (Zohar, 2002). Wujud dari SQ ini adalah sikap moral yang dipandang luhur oleh pelaku (Ummah dkk, 2003).

SQ tidak mesti berhubungan dengan agama. SQ mendahului seluruh nilai spesifik dan budaya manapun, serta mendahului bentuk ekspresi agama manapun yang pernah ada. Namun untuk sebagian orang SQ boleh jadi menemukan bentuk ekspresinya lewat agama formal. Tetapi dengan beragama tidaklah menjamin tingkat SQ yang tinggi. 
Banyak orang yang humanis dan ateis memiliki SQ yang tinggi, dan sebaliknya justru orang yang beragama yang memiliki SQ yang rendah (Sukidi, 2004).

Berbagai penelitian tentang etika memberikan bukti empiris mengenai faktorfaktor yang mempengaruhi sikap dan perilaku etis seseorang yang dapat dikelompokkan kedalam tiga aspek, yaitu: 1) Aspek individual (Emotional dan Spritual); 2) Aspek organisasional; dan 3) Aspek lingkungan. Penelitian tentang etika yang berfokus pada aspek individual menunjukkan berbagai faktor yang mempengaruhi sikap dan perilaku etis seseorang antara lain: a) Religiusitas b) Kecerdasan emosional c) Gender d) Suasana etis (ethical climate) individu e) Sifat-sifat personal dan f) Kepercayaan bahwa orang lain lebih tidak etis (Clark, 1996). Sedangkan aspek lingkungan yang mempengaruhi sikap dan perilaku etis seseorang meliputi: a)Lingkungan organisasi (Verbeke dkk, 1996), dan b) Lingkungan sosial/masyarakat (Ludigdo, 2005).

Dalam menilai sikap etis banyak hal bisa kita lihat dalam kehidupan sehari-hari, namun dalam penelitian ini terdapat beberapa indikator dari sikap etis (Verbeke dkk, 1996) yaitu : 1) Tanggungjawab, dimana seseorang menyelesaikan apa yang menjadi prioritas utama. Robbin dan Judge (2008) menyatakan ini merupakan komitmen afektif (affektive komitmen) dalam hal pekerjaan yang dilakukan; 2) Kepentingan Publik, hal ini cenderung kepada kepentingan secara umum bukan untuk suatu golongan tertentu yang nantinya akan berdampak pada kepuasan pelanggan; 30 Suasana Etis (ethical climate) Individu, menggambarkan hubungan antar pribadi yang melebur dalam satu satuan kerja dimana norma dan etika kerja tetap menjadi acuan utama; 4) Integritas, menunjukkan pengabdian yang telah diberikan oleh karyawan dan tingkat sampai mana karyawan yakin organisasi menghargai kontribusi mereka dan pedui dengan kesejahteraan mereka; 5) Perilaku Profesional, merupakan komitmen berkelanjutan (continuance commitmen) yang menggambarkan komitmen untuk bertahan di sebuah organisasi atau perusahaan dengan menyelesaikan pekerjaan yang telah menjadi tanggung jawab dari awal; 6) Aturan Etika, terdapat dalam komitmen normatif (normative commitmen) yaitu bertahan dengan organisasi untuk alasan moral dan etis, bukan untuk memanfaatkan fasilitas yang diberikan oleh organisasi atau perusahaan.

Nilai merupakan suatu komponen yang tidak berdiri sendiri, karena setiap nilai pasti diawali dari sebuah sikap individu. Winardi (2004) menyatakan bahwa sikap merupakan determinan perilaku karena mereka berkaitan dengan persepsi, kepribadian dan motivasi. Untuk mengubah sikap bukanlah suatu hal mudah karena ada beberapa hal yang dapat mengubah sikap tersebut yaitu : kepercayaan pada pihak yang mengirim pesan, pesan itu sendiri dan situasi yang dihadapi. Sikap dan nilai merupakan nilai-nilai terikat dengan sikap dalam arti bahwa sebuah nilai berguna sebagai suatu cara untuk mengorganisasi sejumlah sikap. Nilai didefinisikan sebagai konstitusi perasaan suka atau tidak menyukai, sudut suatu pandangan, sikap kecendrungan dalam diri sendiri, penilaian-penilaian rasional maupun yang irasional, prasangka-prasangka dan pola-pola asosiasi yang mempengaruhi pandangan seseorang terhadap dunia.

\section{SIMPULAN}

Berdasarkan uraian dan hasil analisis pada bab-bab sebelumnya, maka dapat diambil kesimpulan sebagai berikut : Kecerdasan emosional memiliki pengaruh signifikan terhadap sikap etis pekerja. Dari beberapa dimensi dalam kecerdasan emosional maka yang paling berhubungan kuat terhadap sikap etis pekerja terdapat pada dimensi untuk membina hubungan agar terciptanya integritas terhadap perusahaan. Kecerdasan spritual memiliki pengaruh signifikan terhadap sikap etis karyawan. Hal ini terlihat dalam dimensi yang paling dominan yaitu bersikap fleksibel untuk membentuk prilaku professional seorang pekerja. Kecerdasan emosional dan kecerdasan spiritual secara bersama-sama 
memiliki pengaruh yang signifikan terhadap sikap etis karyawan. Artinya kecerdasan emosional dan kecerdasan spiritual memiliki peran dalam membentuk sikap etis seorang karyawan.

\section{DAFTAR RUJUKAN}

Agustian, Ari Ginanjar 2001. ESQ: Kecerdasan Emosi dan Spiritual. Penerbit Arga: Jakarta. 2006. rahasia sukses membangun kecerdasan dan spritual (ESQ). penerbit Arga: Jakarta

Arikunto, S. 2002. Prosedur Penelitian Suatu Pendekatan. Edisi Kelima. Rineka Cipta. Jakarta.

Armansyah. 2006. Intelegency Quotient, Emotional Quotient, dan Spiritual quotient dalam membentuk perilaku kerja. Universitas Muhammadiyah Sumatera Utara.

Azwar, S. 2004. Sikap Manusia: Teori dan Pengukurannya. Edisi Kedelapan. Pustaka Pelajar, Yogyakarta.

Basuki, Sulistyo. 2007. Kode etik dan organisasi profesi. http://www.consal.org.sg/webupload/for ums/attachments/2270.doc

Bradberry, Travis \& Jead Greaves. 2007. penerapan EQ ditempat kerja dan ruang keluarga. Think. Jakarta

Clark, J.W. \& L.E. Dawson. 1996. Personal Religiousness and Ethical Judgement: An Empirical Analysis. Journal of Business Ethics

Dani, K. 2002. Kamus Lengkap Bahasa Indonesia. Putra Harsa, Surabaya.

Fudyartanta, K. 2004. Tes Bakat dan Perskalaan Kecerdasan. Pustaka Pelajar, Yogyakarta.
Ghozali, I. 2005. Aplikasi analisis multivariate dengan program SPSS, cetakan pertama. Badan Penerbit Universitas Diponegoro. Semarang.

Goleman, D. 2005. Kecerdasan Emosi untuk Mencapai Puncak Prestasi. Cetakan Keenam. PT Gramedia Pustaka Utama, Jakarta. Diterjemahkan oleh Alex Tri Kuntjahyo Widodo dari Working with Emotional Intelligence, 1999.

Goleman, D. 2006. Emotional Intelligence. Cetakan Keenam belas. Diterjemahkan oleh T. Hermaya. PT Gramedia Pustaka Utama, Jakarta.

Idrus, M. 2009. Metode Penelitian Ilmu Sosial. Erlangga. Jakarta.

Kochen, M. "Ethics and information science," Journal of the American Society for Information Science, 38, May 1987:206-10

Ludigdo, U. 2005. Pemahaman Strukturasi Atas Praktik Etika di Sebuah Kantor Akuntan Publik. Ringkasan Disertasi. Program Pascasarjana Universitas Brawijaya, Malang.

Mahzar, Armahedi. 2006. Spiritual intelegent .http:// /references/ www.paramartha.org sqdanah.htm psyche/psyche002/

Mayer, J.D. \& Salovey, P. 1997. What is Emotional Intelligence. New York: Basic

Magnis-Suseno, F. 2005. Etika Dasar Masalah Pokok Filsafat Moral. Cetakan Ketujuhbelas. Kanisius, Yogyakarta.

Mubarok, M Mufti. 2010. "Di balik Kontroversi ESQ Ary Ginanjar Agustian”. Mumtaz Media. Surabaya. 
Nachrowi, D Nachrowi. 2006. "Pendekatan Populer dan Praktis Ekonometrika untuk Analisis Ekonomi Dan Keuangan ". FE UI. Jakarta.

Pendit, Putu (a) . Kode etik. 20 November 2000.___c_s@groups.com. Akses tgl 21 November 2010.

Priyatno, Duwi. 2008. "5 Jam Belajar Olah Data dengan SPSS 17". Andi. Yogyakarta.

Riduwan \& Sunarto. 2011. Pengantar Statistika untuk penelitian Pendidikan, Sosial, Ekonomi, Komunikasi dan Bisnis. Cetakan ke empat. Alfabeta. Bandung.

Robbins, Stephen P \& Judge, Timothy A. 2008. Perilaku Organisas. Buku I edisi 12. Salemba Empat. Jakarta.

Sadana, Stefanus M.S. 2006. Pengelolaan SDM Perbankan Indonesia Era Global. Dies Natalis XXXII STIE Perbanas : Jakarta.

Santoso, K. 2002. Dampak Kebangkrutan Enron terhadap Citra Profesi Akuntan Publik. Media Akuntansi

Shaleh, Abdul Rahman. 2008. Psikologi Suatu Pengantar dalam perspektif Islam. Cetakan ke 3. Kencana Pradana Media Group. Jakarta.

Sevilla, et all. 1993. Pengantar Metode Penelitian. Terjemahan Alimuddin Tuwu. Penerbit Universitas Indonesia (UI Press). Jakarta

Stein, Robert J. 2010. "20 Test Mandiri untuk mengetahui dan memaksimalkan potensi EQ anda, Tes EQ”. Prestasi Pustaka Publisher. Jakarta.

Sukidi. 2004. Spiritual Happienes. http://www.consal.org.sg/webupload/for ums.

Sugiyono. 2009. Metode Penelitian Bisnis (Pendekatan Kuantitatif-Kualitatif dan $R \& D)$. CV Alfabeta. Bandung
Supramono dan I. Utami. 2004. desaign Proposal Penelitian Akuntansi dan keuangan. Penerbit Andi. Yogyakarta.

Svyantek, D.J. 2003. Emotional Intelligence and Organizational Behavior. The International Journal of Organizational Analysis 11 (3): 167169.

Thoha, Mifta. 1983. Perilaku Organisasi Konsep Dasar dan Aplikasinya. PT Rajawali Grafindo Persada. Jakarta.

Tikollah, M. Ridwan, dkk. 2006. Pengaruh $I Q, \quad E Q, \quad S Q$ Terhadap Sikap Etis Mahasiswa Akuntansi. Simposium Nasional Akuntansi: Padang

Ummah, k., D. Mahayana \& A. Nggermanto. 2003. SEPIA: Kecerdasan Milyuner, Warisan yang Mencerahkan Keturunan Anda. Cetakan Pertama. Ahaa, Bandung.

Umar, Husein. 2003. Metode Riset perilaku Organisasi. PT Gramedia Pustaka Utama. Jakarta.

Umar, Husein. 2009. Metodologi Penelitian: Aplikasi dalam Pemasaran. Gramedia. Jakarta.

Umar, Husein. 2010. Desain Penelitian MSDM dan Perilaku Karyawan. Cetakan ke tiga. PT Raja Grafindo Persada. Jakarta.

Verbeke, W; C. Ouwerkerk \& E. Peelen. 1996. Exploring the Contextual and Individual Factors on Ethical Decision Making of Salespeople. Journal of Business Ethics.

Winardi. 2004. Manajemen Perilaku Organisasi edisi revisi. Prenada Media. Jakarta.

Zohar. Danah dan Marshal, Ian. 2002. SQ. "Spiritual Intelligence. the Ultimate Intelligence” Bloomsbury: London. 